\title{
PROMOTING INDONESIAN TOURISM TO CHINESE TOURISTS THROUGH JOURNALISM STRATEGIES IN WECHAT
}

\author{
Hendy Yuniarto \\ Beijing Foreign Studies University \\ hendyyuniarto@yahoo.com \\ DOI: https://doi.org/10.24071/ijhs.2017.010111 \\ received 20 July 2016; revised 30 July 2017; accepted 2 August 2017
}

\begin{abstract}
Indonesia is one of the top ten destinations for Chinese people. In fact, Chinese tourists contributed the highest number of foreign tourists to Indonesia. The innovative access to information facilitated them to plan itinerary in Indonesia. The Indonesian government who aimed at increasing Chinese tourists can implement digital tools. This brief study elaborates the use of journalism to review destinations which were disseminated through Wechat. Various destinations in Indonesia can be informed to more than 800 million of Wechat users. The reviews of a tourism destination are not limited to general or popular destinations, but also to new destinations that have not been known widely. The news structure is divided into 6 sections, including location details, the history, the attraction, how to get to the place, useful information, and the cost. Some obstacles related to translation and the dissemination of the news can be solved by working with some parties to promote this strategy.
\end{abstract}

Keywords: Strategy, Increasing Chinese Tourists, Tourist Journalism, Wechat

\section{Introduction}

In 2016 Indonesian government targeted three million Chinese tourists (Asdhiana, 2016). Indonesian tourism industry contributes greatly to increase the income as well as provides more employment opportunities in different areas, such as transportation services, tour guides, crafts, and food. The tourism industry in Indonesia currently contributes 4 percent of total GDP (Indonesiainvestments.com). There were 11.5 million foreign tourists in 2016 who visited places in Indonesia. The number is less than the number of the tourists who travelled to Thailand (30 million in 2015). The government official website (kemenpar.go.id) mentions that the highest number of foreigners who visited Indonesia is from China. The list is followed by Singapore, Australia, and Malaysia.

The Indonesian government continues to boost the tourism sector by improving infrastructure and developing various promotions to attract foreign tourists. Many Indonesian-themed festivals in several countries were held to introduce Indonesian tourism. Nowadays, some new tourism destination promoted. In Beijing, Indonesia-themed festival fascinates local people. 
Indonesian cultural festival is also performed by Indonesian students at many universities in China to attract students to know about Indonesia.

There are still many Chinese who only know few things and places about Indonesia, such as Bali and Jakarta. Bali is famous for its culture and natural beauty. Some Chinese celebrities married in Bali. This phenomenon also attracted other Chinese people. Having a honeymoon and getting married in Bali are considered the dream of Chinese couples.

Research conducted by Su An Zhi (2017) inspired this brief paper. The study was conducted by involving 342 random respondents among 18-45 years old whose monthly income varied from 600 USD to 4000 USD. There were $22 \%$ of respondents who visited to Bali. More than half of them $(60 \%)$ visited Jimbaran Beach, Kuta Beach and Tanah Lot Temple. Besides those places, they also visited Nusa Lembongan Island, Puri Saren Agung Ubud, Pura Tirta Empul, Tegallalang Rice Terrace, and Nusa Dua. Bali is viewed as a place with beautiful beaches, wedding places, special culture, and friendly people. Beautiful beaches, special culture, and friendly people were common impression that foreign tourists know about. Bali as a wedding place is strongly influenced by the news of various media in China about celebrities who are married and honeymoon in Bali.

Some factors that support Chinese tourists coming to Bali is its natural beauty. Another factor is its tropical climate. Because China has four seasons, Chinese often travel to the south during winter. Furthermore, visa-free is also an important factor to attract these respondents who visited Bali. In addition, the hospitality is also an important aspect to impress the tourists. Indonesian hospitality, indeed, has been well-recognized in many countries. The last factor found in that study is Balinese culinary is very tasty.

In order to support the increasing number of tourists from China to Indonesia, several airlines have opened direct flights. Some direct flights come from various cities, such as Beijing, Shanghai, Hongkong, Guanzhou, and Chengdu (Bayu, 2017). Besides Bali, many tourism destinations should be promoted to attract Chinese tourists. The growth of tourism in Indonesia has entered the world's top 20 and the second in ASEAN (Ramadhanny, 2017). Indonesian President, Joko Widodo, asked the tourism minister to increase the growth of tourism. In order to improve the growth of Indonesian tourism, various strategies can be developed.

This brief paper attempts to propose a strategy to increase Chinese's interest in Indonesian tourism. Through digital information on the Wechat, tourism information in Indonesia can be delivered quickly and effectively. The information can be displayed through innovative journalism methods. Travel journalism serves tourism information as well as composing a story that flows to readers in a travel record style. In an article written by Fitraya Ramadhanny (2015), travel journalism contributes greatly to tourism in Indonesia (Ramadhanny, 2015). Travel journalism is composed based on the rules of journalism, highlighting objectivity. Many new destinations appear due to the viral on social media. Therefore, travel journalism can be used as a method to inform tourist in order to increase the attractiveness of readers to Indonesian tourism. 


\section{Method}

Wechat is China's largest social media with an active number of more than 800 million people (Wan, 2017). Although most Wechat users are Chinese, there are 70 million users 'non-Chinese' in the world. Chinese people do not only use the Wechat app for friendship communication, but also spread the news and business purposes. Various news portals are created and disseminated via Wechat. In addition, Wechat becomes popular for business marketing. Therefore, Wechat can now be used to disseminate any information according to the purpose of its users.

Wechat has a wider range of features than many other chat apps. Wechat can be used to deposit money and make online payments to someone or to various street vendors. If we want to buy snacks at the roadside we do not need to use cash if the seller receives payment via Wechat. In addition, Wechat can be used to make money transactions quickly and convenient. The next interesting feature is we can do various kinds of online payment for various purposes, such as buying transportation and cinema tickets or to rent a bike on the roadside.

To maximize Wechat's feature as a broadcasting media, it needs a creative strategy to attract readers. One of the strategies to provide attractive information is by using travel journalism. Fundamentally, travel journalism is one type of journalism that focused on travelling (Arismunandar, 2010). Travel journalism begins with diaries written by explorers such as Marcopolo who travelled to East Asia in the 13th century, Xuanzang's journey from China to India in the 7th century, and also Cheng Ho's maritime expeditions in the $15^{\text {th }}$ century.

Fürsich and Kavoori (2001) described five important factors of studying travel journalism. First, the tourism industry is growing. Second, there have not been so many studies of tourism and its impact on the social life. Third, tourism is a social activity that is now commonly done by a lot of people. Fourth, travel journalism is as important as international communication that provides knowledge. Fifth, travel journalism can be potential in the future. The study of travel journalism is possible with a variety of purposes (Folker, 2010:68-82). The main objective in travel journalism is to describe and inform the public about tourism destinations in an interesting way and cling on the journalistic principles. The method of travel journalism is considered to become more flexible with a focus to inform the truth about the place and community (Hill-James, 2016).

This concept can be applied to record all forms of the travel activity. It can be served in the form of tourism news informing target audience. Many topics can be written via travel journalism, such as mountains, oceans, rivers, lakes, waterfalls, grasslands, and caves. In addition, we can also write about cities, historical places, culinary, social life, and cultural traditions in certain places. The willingness of journalists to be able to go into the fields and interact with the local community is a must. Local and foreign language skills also are important to communicate and write a report about the destination.

Searching for information through other sources such as the internet and related expert interviews can also be made to add or compare the results of direct observations. Some places have been summarized and reported by previous journalists. But in the previous report we can find outdated information, such as 
the change of bus lines and the change of living costs, such as the cost spent for hotels, restaurants, phone numbers, and other information. Therefore, updated information will complement the news that has been written previously.

The information presented in the Wechat platform is expected to get many readers so that it becomes viral. Wechat is a very effective app to introduce various interesting destinations to Chinese people about tourism in Indonesia. The main obstacle in the delivery of information is language. The Chinese use Mandarin as the national language. Therefore, all the information compiled must be translated into Mandarin.

\section{Findings and Discussion}

Choosing a potential tourism destination is considered to be more effective than reviewing widely known places. A freelance journalist, Jill Starley (2012) says that a travel journalist can review less popular destinations (Starley, 2012). In fact, some people are very interested in new destinations that are not popular yet. The result will attract the attention of readers to be more curious to visit new destinations. In Yogyakarta, Prambanan temple, King Palace, and Parangtritis beach is a place that is commonly known by tourists. Besides popular tourist destinations, there are many other places that are much more interesting. In fact, in Yogyakarta there are various kinds of tourism destinations such as mountains, museums, beaches, shopping centres, newly opened art performances. So far, the availability of such information is still limited to the Chinese tourists.

Introducing new destinations is the proper strategy to increase foreign tourists. I take the example of three new tourism destinations in Yogyakarta. First, Mount Nglanggeran as a new tourism destination in the east of Yogyakarta. The mountain that has an elevation of 700 meter is often called the ancient volcano because 60 million years ago, it was an active volcano (Pramesti, 2012). This brand new destination has attracter hikers. Tourists can climb the mountains and walk around countryside while enjoying the beautiful natural scenery. Information about Mount Nglanggeran is available on internet pages. Considering all facilities have been sufficient, then the destination has been feasible to be promoted internationally, especially to the Chinese tourists.

Beside Mount Nglanggeran, many beaches in Gunung Kidul region are also worth to be reviewed and presented to the online media. Recently, the beaches in Gunung Kidul are increasingly visited by domestic tourists. New beaches have been opened to public and more facilities were added in order to make the visitors more comfortable. The popularity of parangtritis beach seems to be increasingly faded due to the number of new beaches in Gunung Kidul. In 2017, former president of America, Obama visited a new tourism destination in Yogyakarta, namely Becici Peak in Bantul region (Diah, 2017). Becici Peak is a 4.4 hectare pine forest where tourists can hike while enjoying the cool air. Therefore, this new destination can also be reviewed into attractive news and presented in Wechat.

The news that is presented on Wechat platform is a kind of informative and attractive short news. Besides the news report, various interesting photos and videos can be added. Photography skills are indispensable in travel journalism to enhance a positive image. Therefore, one piece of news can contain 3 forms of information: reports, pictures, and videos. 
The news contains all reviews related to tourism destinations. The structure of the news content in this paper is divided into 6 sections, including: location details, the history, attraction, how to get to the place (direction), useful information, and the cost. The location details can be shown with images from maps to make it easier for readers to know the location of the destination. The history of the destination, for example various temples in Java and some other historical places, should also be displayed. The attraction includes what tourists get at the location. For example, in Kotagede, Yogyakarta, there are many silver craftsmen and silver handicrafts promoted in eksotisjogja.com. Visitors can see how to make accessories or jewellry from silver and buy them directly at that location. How to get to tourist destinations is indicated by the availability of transportation to the location, especially public transportation. Useful information aims at informing the readers of general conditions related to geography, social, and general circumstances in tourism sites. All the recommended information regarding lodging, food and shopping also can be informed to the readers. The cost estimation is an optional aspect in tourism news. It facilitates visitors to know the range of expenses to get to the destination. Therefore, the structure of news content can be presented as follows.

\begin{tabular}{|ll|}
\hline 1. Lews Content \\
2. The history \\
3. Attraction \\
4. How to get to the \\
place \\
5. Useful information \\
6. Cost \\
\hline
\end{tabular}

The location details are the earliest aspects featured in the news. Locations are not only described by showing the address clearly, but also telling the easiest ways to identify surroundings. To show Malioboro Street as a shopping centre in Yogyakarta city, we can add a description of the prominent places near Malioboro street, for example Post Office, Train Station, and hotels. By telling the distance between the nearest places to the Malioboro Street, it is easier for tourists to find locations on the map with the additional places. Although Malioboro Street is located in the centre of the city and clearly visible on the map, but tourists come from various directions. Therefore, showing places around is very important to make it easier for visitors to search the places.

The history of the destinations can be explained briefly and informatively. The explanation depends on the place's history. Yogyakarta Palace can be explained together with the history of various kingdoms and kings in the past. Descriptions can be written by revealing history in the form of general and interesting facts. For example, the Yogyakarta Palace keeps various precious art treasures. Therefore, by looking at the various relics of the kings, the visitors can imagine the past royal life in Yogyakarta. By writing an interesting history, surely, the reader will consider the place as a tourist destination. 
The aspect of attraction is arranged by explaining the advantages of the tourism site. It will not be adequate to describe the beaches of Gunungkidul as places with beautiful scenery only. Journalists should be able to describe in more details by adding fine white sand, calm waves, clear water, and chilly breeze. In addition, on-site facilities such as comfortable hotels, cheap restaurants, and friendly service can be highlighted as a way to attract visitors. The aspect of attraction is the most important part of the news so it can really affect the readers' trust, especially when there are photos and videos which are made to support the news.

The aspect "how to get to the location" can be composed by providing transportation routes leading to the location. First, the location can be reached by taxi from the airport. Second, journalists should notify bus or train lines to get to the location. Third, if the distance of the location is very close, then the author can recommend walking. Special transportation which is the main attraction in Yogyakarta is the horse-cart and pedicab. Those transportations can also be an alternative transportation to the destinations. Each kind of transportation has advantages and disadvantages. At certain times there is also traffic jam to be explained so tourist can anticipate it.

The aspects related to useful information are presented in the form of interesting tips about the destination. In Malioboro visitors can bargain the price offered by the sellers. In addition, visitors can enjoy live traditional music performances for free at night. Surrounding Malioboro Street, there are many lodging in affordable price. If visitors want to eat on the roadside, remind them to ask information of the price first. All these tips are gained from previous experiences. Therefore, journalists should be sensitive to various tips on location to make tourists more comfortable.

Cost estimation becomes a very useful aspect for the readers as it is related to the financial plan that will be considered when visiting certain destination. The costs include transportation, hotels, food, tickets, and other expenses. Although some places have been included in the tour package with a fixed price, but new places do not have any information regarding cost estimation. As a result, many tourists experienced when finding information related to accommodation and other costs. Therefore, given the approximation cost, readers can plan and manage the expense easily.

The responsibility of journalists is to write the truth details of the tourism sites. The geography and temperature of the sites are very important to be informed so that tourists can prepare themselves before going to the location. A journalist is also expected to become more sensitive to the social conditions of a community at the location. The customs of a society that have become traditions and prohibitions should be informed to avoid misunderstandings between local people and tourists. For example, tourists who visit the temple of Borobudur are not allowed to climb or step on the stupa because the temple of Borobudur is a place of worship for Buddhists. Therefore, balanced reporting becomes the foundation of journalists in making their travel reports.

The first obstacle and challenge are ways to review new destinations and translate the information in Mandarin. Therefore, to attract Chinese tourists, the journalist is expected to review tourist destinations in Mandarin and spread it on 
Wechat. Indeed, journalists can seek help from translators or compose the news by themselves. News can also be written in English, but the number of readers will not be as satisfying as the number of readers when the news is translated into Mandarin.

Secondly, it is vital to think of ways to disseminate the news to Chinese society. Wechat is considered as the most popular social media in China. The news can be disseminated from one's account to another through the sharing feature called "moment". In addition, we can also create a special news platform in Wechat to load the news. It can be updated regularly or even anytime. This platform can be used by a journalist to publish news about tourism. To spread the news, we need to cooperate with various parties in order to reach broadly. Some parties that are considered effective to be invited to cooperate in supporting the dissemination of the news including student groups, embassies, the study centre of Indonesia, tourism groups, and national or international media.

The last obstacle and challenge are how to support the production of the news financially. The funding can be done by joining with various parties. Travel agents can be invited to work together to fund the creation and translation of news. In addition to travel agents, government agencies can also be invited to work together to support the dissemination of news in Wechat. Although without financial support, news production activities can be done independently, but it will be not effective due to financial limitation. Therefore, to implement tourism in Wechat, some of these obstacles must be solved. Finally, the strategies to increase Chinese tourists can be well realized.

\section{Conclusion}

Creative and innovative strategies are expected to be effective in promoting Indonesian tourism and inviting larger number of tourists. Tourism journalism presented in the news on Wechat can promote Indonesian tourism. The reviews of tourism sites do not only cover famous destinations offered by travel agents. On the other hand, new destinations should be introduced in tourism news. The structure should consist of 6 parts including the location details, the history, the attraction, the directions on how to get to the place, useful information, and the cost.

Since the target audience is Chinese, the news should be translated into Mandarin before exposed in that World Wide Web. Therefore, the main obstacle that should be anticipated and solved is the ability of journalists to write in Mandarin. An alternative way to overcome these obstacles is to work with translators. To spread the news, journalists should work together with various parties, such as the embassies, the centre of Indonesian studies, some media, and Indonesian students in China.

\section{References}

Anonymous. (2016). Industri pariwisata Indonesia. Retrieved on July 15, 2017, from www.indonesia-investments.com/id/bisnis/industrisektor/pariwisata/item6051? 
Anonymous. (2016). Jumlah kunjungan wisatawan mancanegara dari bulan Januari-Desember 2016. Retrieved on July 15, 2017, from kemenpar.go.id

Anonymous. (2016). Kotagede pusat kerajinan perak di Yogyakarta. Retrieved on July 24, 2017, from, eksotisjogja.com/kotagede-pusat-kerajinan-perakyogyakarta/

Anonymous. (2017). Jalan malioboro, the 24 hours street. Retrieved on July 15, 2017, from tourjogja.com/read/18/malioboro-the-24-hours-street.html/

Anonymous. (2017). Tujuan populer Asia Tenggara. Retrieved on July 15, 2017, from vacations.ctrip.com

Arismunandar, S. (2010). Mengenal jurnalisme perjalanan (travel journalism) dan program jelajah. Retrieved on July 16, 2017, from www.academia.edu/4980098/Mengenal_Jurnalisme_Perjalanan_Travel_J ournalism dan Program Jelajah

Asdhiana, I. M. (2014). Target 3 juta wisatawan tiongkok tahun 2016. Kompas. Retrieved on July 15, 2017, from travel.kompas.com/read/2014/08/23/ 202004227/

Bayu, D. J. (2017). Berkat penerbangan langsung, turis asal tiongkok serbu indonesia. Retrieved on July 16, 2017, from katadata.co.id/ berita/2017/07/04/ gunakan-penerbangan-langsung-turis-asing-asalchina-serbu-indonesia

Diah. (2017). Hari kedua di Yogyakarta, Obama ke puncak Becici Dlingo. Retrieved on July 18, 2017, from www.balipost.com/news/2017/07/01/13299/

Hanusch, F. (2010). The dimensions of travel journalism: Exploring new fields for journalism research beyond the news. Journalism Studies, 11(1). doi: 10.1080/14616700903290569.

Hill-James. (2006). Citizen tourist: Newspaper travel journalism's responsibility to it's audience (Thesis). Queensland University of Technology.

Pramesti, O. L. (2012). Gunung api purba di Yogyakarta. Retrieved on July 18, 2017, from nationalgeographic.co.id/berita/2012/10/gunungnglanggeran-gunung-api-purba-

Ramadhanny, F. (2015). Ternyata travel journalism berkontribusi besar untuk pariwisata Indonesia. Retrieved on July 16, 2017, from travel.detik.com/travel-news/d-2922996/

Ramadhanny, F. (2017). Pariwisata indonesia sudah 20 besar dunia, jokowi minta digenjot lagi. Retrieved on July 16, 2017, from travel.detik.com/travel-news/d-3560850/pariwisata-indonesia-sudah-20besar-dunia-jokowi-minta-digenjot-lagi?_ga/

Starley, J. (2012). Breaking into travel journalism: Advice from the expert. Retrieved on July 18, 2017, from theguardian.com/careers/breaking-intotravel-journalism

Wan, A. (2017). Seven interesting facts about wechat. Retrieved on July 15, 2017, from peripherydigital.com/blog/7-interesting-facts-wechat

Zhi, S. A. (2017). Faktor-faktor daya tarik pariwisata bali dari sudut pandang orang tiongkok (Thesis). Beijing Foreign Studies University. 